\title{
AZADIRACHTIN EFFECTS ON PROTEINS SYNTHESIZED IN FAT BODY, HAEMOLYMPH, OVARY AND MID-GUT OF LOCUSTS, SCHISTOCERCA GREGARIA.
}

\author{
P. A. PARANAGAMA ${ }^{1 *}$, J. D. CONNOLLY ${ }^{2}$ and R. H. C. STRANG ${ }^{3}$ \\ ${ }^{1}$ Department of Chemistry, University of Kelaniya, Kelaniya. \\ ${ }^{2}$ Department of Chemistry, University of Glasgow, Glasgow, U.K. \\ ${ }^{3}$ Department of Biochemistry, University of Glasgow, Glasgow, U.K.
}

(Received: 09 October 2002; accepted: 03 April 2003)

\begin{abstract}
H}$-glycine was used as a tracer to examine the effect of azadirachtin on the incorporation of the amino acid into protein in various tissues, both in vivo and in vitro. In locusts, the tissues examined were fat body, ovary and mid-gut. The injected tracer rapidly moved from the haemolymph into many of the tissues. A large fraction of the tracer was present in the fat body as well as in the gut and ovary. It was found that the terpenoid eliminated the stimulatory effects of crude neurohormonal extracts from corpus cardiacum on protein synthesis in fat bodies and ovary. Azadirachtin appeared to have a direct inhibitory effect on protein biosynthesis in the mid-gut and this could be partly accounted for by secondary antifeedant effects.
\end{abstract}

Key words: Azadirachtin, fat body, ${ }^{3} \mathrm{H}$-glycine, mid-gut, ovary, Schistocerca gregaria

\section{INTRODUCTION}

Azadirachtin, a tetranotriterpenoid, the major component in neem, Azadirachta indica, was first isolated in pure form by Butterworth and Morgan in 1971. The primary effect of azadirachtin on insects is its strong antifeedant activity. The desert locust, Schistocerca gregaria, is particularly sensitive to azadirachtin. Many biological effects of azadirachtin, such as growth disruption, fecundity, fitness reduction and oviposition, are well documented, although its effects at the cellular level are still unknown. ${ }^{1,2,3,4,5}$

The mode of action of azadirachtin was studied using radiolabelled dihydroazadirachtin which exerts the same biological effect as azadirachtin. It was reported that the compound is taken up apparently with great specificity into nearly all tissues examined. A large fraction of the radiolabelled compound was absorbed into the gut, Malpighian tubules and nervous tissues. The uptake of $\left[22,23-{ }^{3} \mathrm{H}_{2}\right]$ dihydroazadirachtin was inhibited by a large excess of injected dihydroazadirachtin, suggesting that the uptake was not due to diffusion. ${ }^{6}$

The aim of the present study was to examine the incorporation of radiolabelled amino acid into the proteins of a number of identified tissues to determine whether, in fact, azadirachtin can be shown to have a general effect on protein biosynthesis

* Corresponding author 
in the locust. The tissues examined for this purpose were fat body, haemolymph and ovary. These tissues are linked in the formation, transport and uptake of vitellogenin and possibly other proteins. The effects of azadirachtin on the biosynthesis of proteins by the mid-gut was also examined, as any reduction of activity of proteolytic and other digestive enzymes could be expected to have a profound effect on the growth of the insects. The tracer used was tritiated glycine, as this had been previously found to be a suitable amino acid for this purpose. ${ }^{7}$

\section{METHODS AND MATERIALS}

Insects: Schistocerca gregaria was purchased from Blades Biological, Edenbridge, Kent, and maintained under laboratory conditions in metal cages at a temperature of $28-30^{\circ} \mathrm{C}, 40 \% \mathrm{r} . \mathrm{h}$. and a $12 \mathrm{~h}$ light $-12 \mathrm{~h}$ dark cycle. The insects were fed on freshly washed spring cabbage leaves. Fresh tap water was also supplied. Cages were cleaned daily. Seven day old female locusts (after the final ecdysis) were used for all experiments. Each experiment was replicated four times.

Azadirachtin treatment: Azadirachtin was extracted and purified from Sri Lankan neem seeds by established methods. ${ }^{6,89}$ Confirmation of the purity of azadirachtin was carried out by melting point $\left(150-152^{\circ} \mathrm{C}\right)$, TLC, reversed phase HPLC and NMR analysis. ${ }^{6}$ Azadirachtin was dissolved in $10 \%$ ethanol to give a final concentration of $1 \mathrm{mg} / \mathrm{ml}$ of azadirachtin. The experimental locusts were injected with a dose of $3 \mu \mathrm{g}$ azadirachtin/g body weight and the control insects starved for $12 \mathrm{~h}$ before the experiment, received the same amount of $10 \%$ ethanol/g body weight as the azadirachtin-treated locusts.

Application of ${ }^{3} \mathrm{H}$-glycine: ${ }^{3} \mathrm{H}$-glycine was obtained from Amersham International, Aylesbury, Bucks. The specific activity of the ${ }^{3} \mathrm{H}$-glycine was $21 \mathrm{Ci} / \mathrm{mmol}$. The radiolabelled amino acid was dissolved in insect saline to give a final concentration of $1 \mu \mathrm{Ci} / 10 \mu \mathrm{l}$. The amino acid $(2 \mu \mathrm{Ci} / \mathrm{g})$ was injected into each locust $12 \mathrm{~h}$ after injection of azadirachtin. Injections were made through the abdominal intersegmental membrane using a Hamilton $25 \mu$ l syringe.

Loss of radioactivity from the haemolymph: Loss of radioactivity from the haemolymph was measured over an $8 \mathrm{~h}$ period by taking $1 \mu \mathrm{l}$ blood samples from the base of the hind coxa of the locust using $5 \mu \mathrm{l}$ micropipettes at different times after injections of the label and the radioactivity within each sample was measured by scintillation counting. Duplicate samples were taken for scintillation counting. Each experiment was replicated four times.

Incorporation of radioactivity into total proteins of whole insects: Initially, the rate of incorporation over $6 \mathrm{~h}$ was measured in both control and azadirachtin-treated locusts. The radioactivity in the whole locust was analyzed in the following manner. Individual locusts were anaesthetized in an atmosphere of $\mathrm{CO}_{2}$ at different times 
after injection of the labelled amino acid and were then frozen in liquid $\mathrm{N}_{2}$, before grinding to a uniform powder in a mortar pre-cooled with liquid $\mathrm{N}_{2}$. The pooled samples were homogenized for $30 \mathrm{~s}$ in $0.5 \mathrm{ml}$ of $5 \%$ trichloroacetic acid (TCA) using an ultrasonic microprobe. Samples were kept deep frozen in $5 \%$ TCA until processing.

The homogenate was centrifuged for $5 \mathrm{~min}$ at $10,000 \mathrm{~g}$ and the pellet washed three times in $5 \%$ TCA. This process removed the entire radioactivity not incorporated into the proteins. The protein pellet was redissolved in $200 \mu \mathrm{l}$ of $0.1 \mathrm{M}$ $\mathrm{NaOH}$ containing $0.1 \% \mathrm{w} / \mathrm{w}$ SDS overnight at $30^{\circ} \mathrm{C}$, and $100 \mu \mathrm{l}$ of the sample was used to estimate the radioactivity by scintillation counting. The rest of the sample was used for protein estimation by the method of Lowry et al.,${ }^{10}$ against a standard of bovine serum albumin, and the specific activity of the tissue was estimated with reference to the protein content.Each experiment was replicated four times.

Incorporation of ${ }^{3} \mathrm{H}$-glycine into specific tissues: The locusts were anaesthetized under $\mathrm{CO}_{2}$ at different times after injection of the radioactive amino acid and the tissues were quickly dissected out under ice-cold insect saline. They were washed in fresh insect saline before being placed in $0.5 \mathrm{ml}$ of $5 \% \mathrm{TCA}$. The samples were homogenized as described before. Tissues examined were the fat body, the haemolymph, the ovary and the mid-gut. Each experiment was replicated four times.

\section{Effect of extracts from neuroendocrine tissue on the protein turnover}

Preparation of corpus cardiacum extraction: Adult female locusts ( 7 days after final ecdysis) were anaesthetized under $\mathrm{CO}_{2}$ and the heads removed. The corpus cardiacum was dissected out, free of the fat body, under saline, and placed in $100 \mu \mathrm{l}$ of insect saline. The gland was homogenized for $30 \mathrm{~s}$ using an ultrasonic microprobe.

Effect of extracts of corpus cardiacum on the rate of incorporation of ${ }^{3} \mathrm{H}$-glycine into the specific tissues of the locusts

The locusts were head-ligatured $12 \mathrm{~h}$ before injection of the ${ }^{3} \mathrm{H}$-glycine and only the experimental locusts were injected with azadirachtin along head-ligation. The incorporation levels of the tissues were measured $2 \mathrm{~h}$ after injection of the ${ }^{3} \mathrm{H}$-glycine in both control and azadirachtin treated locusts. The above experiment was extended as follows to observe the effect precisely. The crude extract of equivalent single corpus cardiacum was injected into each ligatured locust $3 \mathrm{~h}$ after injection of ${ }^{3} \mathrm{H}$-glycine, and then the rate of incorporation was measured.

To determine whether there is any direct physical effect on the uptake of amino acids due to ligation, the clearance of ${ }^{3} \mathrm{H}$-glycine from the haemolymph was measured in both control and azadirachtin treated locusts. 
The in vitro work was carried out with all the tissues examined in vivo separately, in an attempt to distinguish between the direct and indirect effects of azadirachtin.

In vitro experiments

Incorporation of ${ }^{3} \mathrm{H}$-glycine into specific tissues of the locust: The locusts were anaesthetized under $\mathrm{CO}_{2}$ and dissected in insect saline. The fat body was removed from the locusts and freed from the ovary and tracheae. The sheets of the fat body were pre-incubated separately in $1 \mathrm{ml}$ of insect saline at $30^{\circ} \mathrm{C}$ for $30 \mathrm{~min}$, and then $1 \mathrm{mCi}$ of ${ }^{3} \mathrm{H}$-glycine was added to the medium. Incorporation of the radiolabel into protein was measured after 1,2 and $4 \mathrm{~h}$.

Subsequently, the experiments were done using ovary and mid-gut and the incorporation rate was measured after application of ${ }^{3} \mathrm{H}$ - glycine into the medium. The control experiment was carried out with the locust tissues which were pre-incubated with $12 \mu \mathrm{g}$ of azadirachtin in the same way as in the medium was same as the in vivo experiment. The insect saline was maintained at a constant temperature of $30{ }^{\circ} \mathrm{C}$ and aerated throughout the experiment. Each experiment was repeated four times.

Effect of neurohormonal extract on incorporation of ${ }^{3} \mathrm{H}$ - glycine into the fat body: Insect saline ( $1 \mathrm{ml}$ ) containing the extract of a single corpus cardiacum was used as the medium for incubation of tissues and then the rate of incorporation was measured as above. The experiments were carried out for both control and azadirachtin-containing media.

Effect of boiling on the corpus cardiacum extraction: In an attempt to determine the nature of the neurosecretory proteins, the extract of corpus cardiacum was boiled for $5 \mathrm{~min}$ and $10 \mathrm{~min}$ and this added to $1 \mathrm{ml}$ of insect saline and the experiment conducted as above.

\section{RESULTS}

\section{Loss of radioactivity from the haemolymph}

The clearance of ${ }^{3} \mathrm{H}$-glycine from the haemolymph was measured over $8 \mathrm{~h}$. The percentage of radioactivity remaining in the haemolymph is shown in Figure 1. More than $60 \%$ of the radioactivity was lost from the haemolymph within the first $30 \mathrm{~min}$ of injection and $8 \mathrm{~h}$ of injection and only $30 \%$ of the total radioactivity was detectable. In the azadirachtin-treated locusts, the clearance of labelled amino acid from the haemolymph showed the same rate as control locusts. The results (Figure 1) show that the uptake of label is exponential, but there appears to be more than one mechanism of uptake. 


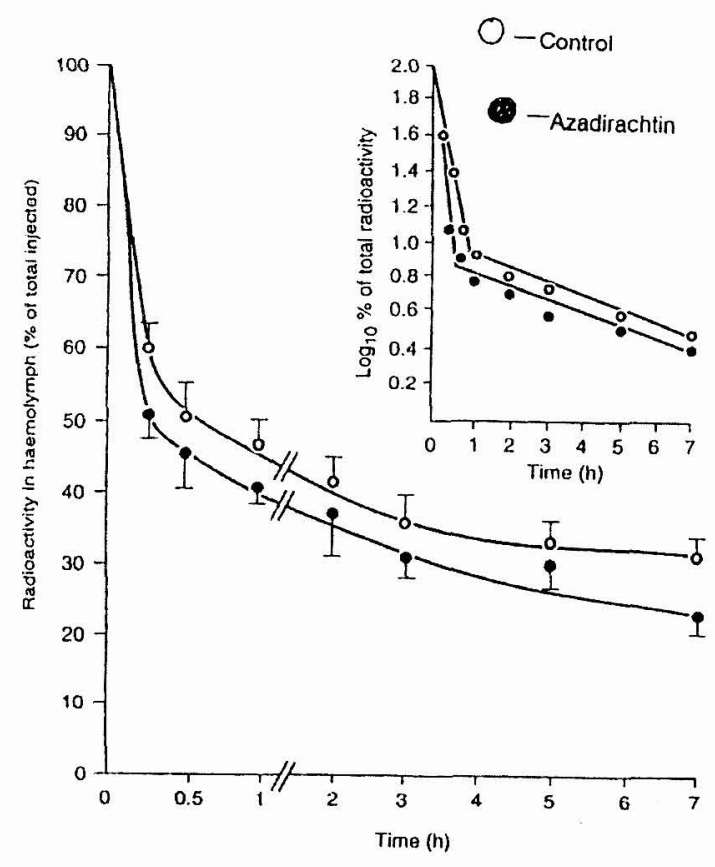

Figure 1: Clearance of radioactive amino acid from the locust haemolymph.

The points are the mean of 4 locusts, and the vertical bars indicate the standard deviation. The upper curve indicates the semilogarithmic representations of the uptake of ${ }^{3} \mathrm{H}$-glycine from the locust haemolymph.

\section{Incorporation of radiolabelled amino acid into total protein in whole locusts}

The rate of incorporation over $6 \mathrm{~h}$ of ${ }^{3} \mathrm{H}$-glycine into the proteins of the 7 day old female adult locusts is shown in Figure 2. This preliminary experiment demonstrated a linear incorporation rate of radiolabelled amino acids into the locust tissue proteins during the first hour after injection, followed by the attainment of an equilibrium level. The incorporation rate was significantly greater in control locusts than in azadirachtin-treated locusts and it was found that $50 \%$ inhibition of the level of incorporation was due to azadirachtin.

\section{Incorporation of ${ }^{3} \mathrm{H}$-glycine into specific tissues of the locusts}

Following the initial experiment, the rate of incorporation of ${ }^{3} \mathrm{H}$-glycine into the fat body, the haemolymph, the ovary and the mid-gut were measured over $6 \mathrm{~h}$ to investigate precisely the effect of azadirachtin on individual tissues. 


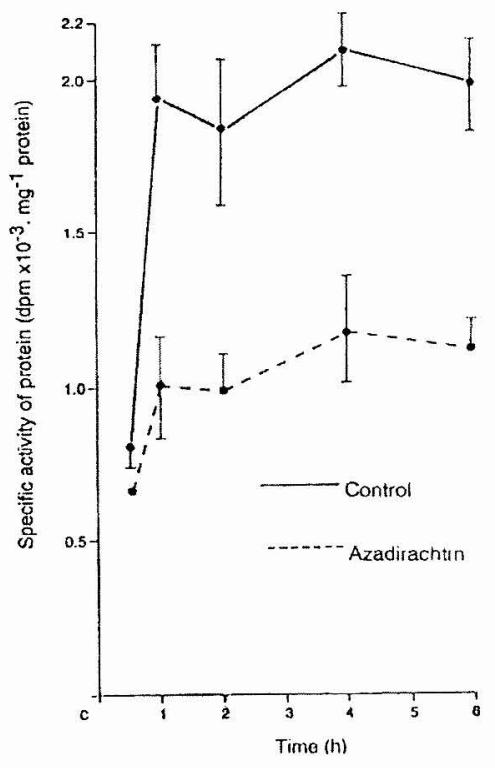

Figure 2: The time course of incorporation of ${ }^{3} \mathrm{H}$-glycine into the proteins of whole locusts.

The values represent the mean $( \pm S D)$ of 4 locusts. The effects of azadirachtin were significantly different $(\mathrm{p}<0.01)$ from the control at each time recorded.

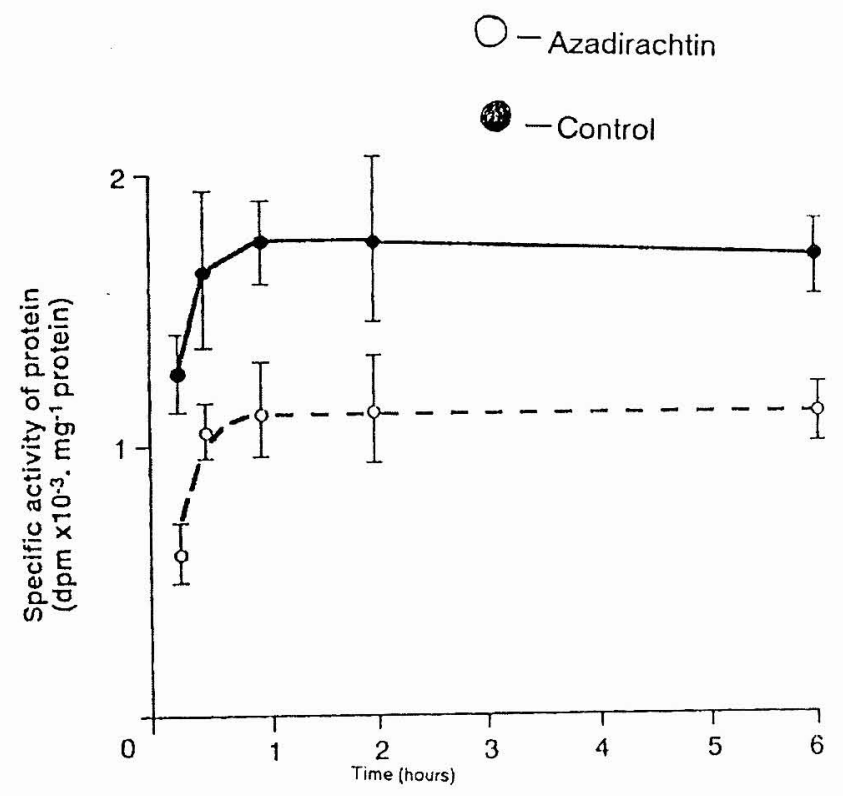

Figure 3: The incorporation of ${ }^{3} \mathrm{H}$-glycine into the proteins of fat body.

The values represent the mean $( \pm S D)$ of 4 locusts. The effects of azadirachtin were significantly different $(\mathrm{p}<0.01)$ from the control at each time recorded. 


\section{(a) Incorporation of ${ }^{3} \mathrm{H}$-glycine into the proteins of fat body}

Figure 3 shows the time course of incorporation of ${ }^{3} \mathrm{H}$-glycine into the fat body of the 7 day old female adult locust. Both groups showed maximum incorporation level at 1h after injection. In the azadirachtin-injected locusts, the incorporation of radiolabelled amino acid into the protein was not as efficient as in the control locusts. At the end of the $1 \mathrm{~h}$ period, the incorporation levels of azadirachtin-treated locusts was $43 \%$ of that of controls. These values were significantly different from each other.

\section{(b) Incorporation of ${ }^{3} \mathrm{H}$-glycine into the haemolymph proteins}

The incorporation of ${ }^{3} \mathrm{H}$-glycine into the haemolymph proteins was measured over $6 \mathrm{~h}$. The results of the time course of incorporation of ${ }^{3} \mathrm{H}$-glycine into the haemolymph proteins of the locust are shown in Figure 4. The level of incorporation was very slow compared to that of the fat body. Both control and azadirachtin-treated locusts showed a level of incorporation, which increased gradually with time. The incorporation level did not reach equilibrium $1 \mathrm{~h}$ after injection as in the fat body. The control locust showed a higher level of incorporation than the azadirachtintreated locusts but these differences did not show any statistical significance.

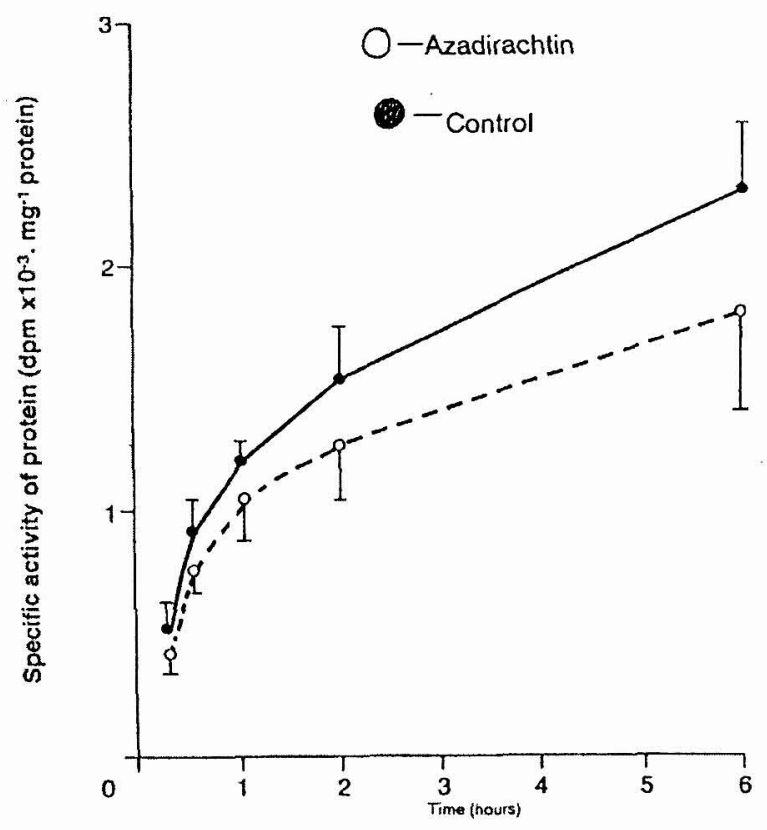

Figure 4: The incorporation of ${ }^{3} \mathrm{H}$-glycine into the haemolymph proteins.

The values represent the mean ( $\pm S D$ ) of 4 locusts. The effects of azadirachtin were significantly different $(p<0.01)$ from the control at each time recorded. 


\section{(c) Incorporation of ${ }^{3} \mathrm{H}$-glycine into the proteins of ovary}

Figure 5 shows the incorporation of ${ }^{3} \mathrm{H}$-glycine into the proteins of ovary of adult female locusts 7 days after final ecdysis. The level of incorporation of the ovary was higher than that of the fat body and the haemolymph. The incorporation rates of control locusts were faster than those of the azadirachtin-treated locusts.

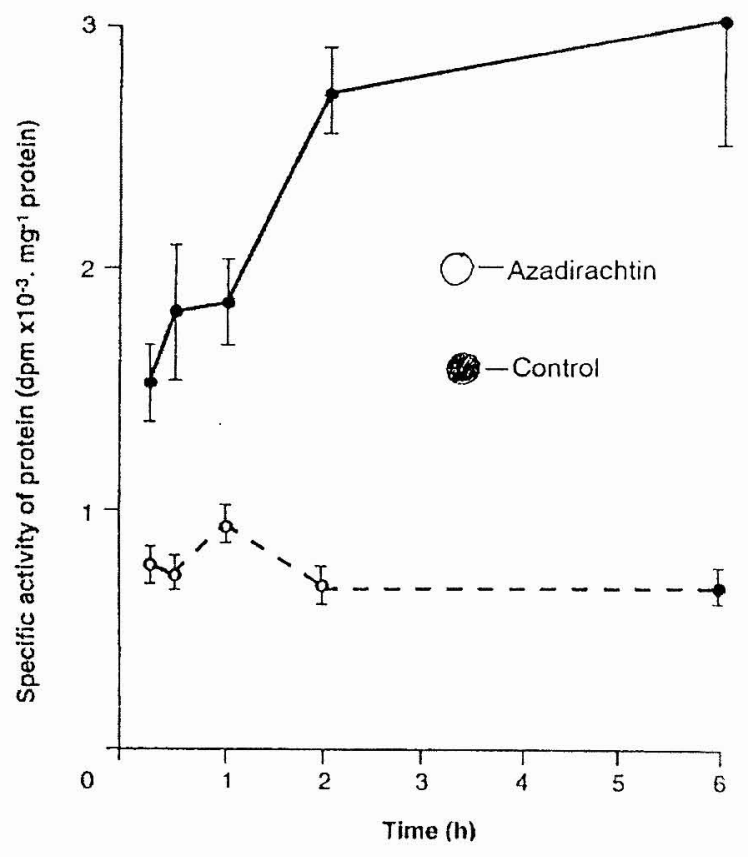

Figure 5: The incorporation of ${ }^{3} \mathrm{H}$-glycine into the proteins of ovary.

The values represent the mean $( \pm \mathrm{SD})$ of 4 locusts. The effects of azadirachtin were significantly different $(p<0.01)$ from the control at each time recorded.

At the end of one hour period, the maximum incorporation level was reached and the incorporation level of the azadirachtin-injected locusts was $27 \%$ that of the controls. Consequently, azadirachtin strongly inhibited the incorporation of amino acids into the ovary.

\section{(d) Incorporation of ${ }^{3} \mathrm{H}$-glycine into the proteins of mid-gut}

The level of incorporation into the mid-gut protein is the same as in the ovary. The results of the incorporation of ${ }^{3} \mathrm{H}$-glycine into the mid-gut is shown in Figure 6. The equilibrium level of incorporation was seen $1 \mathrm{~h}$ after injection of radiolabelled glycine. Azadirachtin inhibited the incorporation of ${ }^{3} \mathrm{H}$-glycine into the mid-gut proteins compared to the control locusts and at the end the incorporation level of azadirachtin-treated locusts was $40 \%$ of that of the controls. 


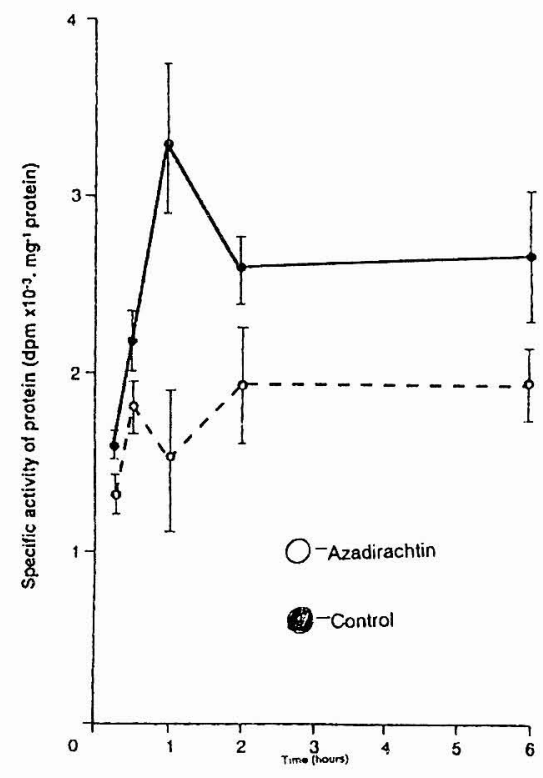

Figure 6: The incorporation of ${ }^{3} \mathrm{H}$-glycine into the mid-gut of the locusts.

The values represent the mean $( \pm \mathrm{SD})$ of 4 locusts. The effects of azadirachtin were significantly different $(\mathrm{p}<0.01)$ from the control at each time recorded.

\section{Effect of extracts of corpus cardiacum and azadirachtin on the rate of incorporation of ${ }^{3} \mathrm{H}$-glycine into specific tissues}

Figure 7a shows the effect of neurohormones and azadirachtin on the level of incorporation of ${ }^{3} \mathrm{H}$-glycine $2 \mathrm{~h}$ after injection. The tissues taken for the analysis were the fat body, the haemolymph, the ovary and the mid-gut. Both the fat body and the ovary showed different response. In the preliminary experiment, the control locusts showed a higher level of incorporation than in the azadirachtin treated locusts as described above. In order to determine the neurohormonal effect on the level of incorporation, the locusts were ligatured $12 \mathrm{~h}$ before injection of radiolabelled glycine, subsequently, the effect of azadirachtin was also examined by injecting it into the haemolymph of the ligatured locusts (Figure 7b). In both groups, the levels of incorporation into the fat body, the haemolymph and the ovary were very similar to each other and the uptake of glycine into protein of these locusts was dramatically reduced to below $50 \%$ of that of the control. The mid-gut showed high levels of incorporation in both ligatured locusts and azadirachtin treated locusts but this level was lower than in the control locusts.

To establish the effect of an extract of corpus cardiacum on the uptake of glycine into the proteins more precisely, the extract of corpus cardiacum was injected into both control and azadirachtin treated ligatured locusts, $3 \mathrm{~h}$ before injection of radiolabelled glycine (Figure $7 \mathrm{c}$ ). The results show that the neurohormonal extract 
increased the uptake of glycine into proteins of the tissues in ligatured insects but the azadirachtin treated locusts did not show the stimulatory effect on the corpus cardiacum extract. This was true for all tissues examined.

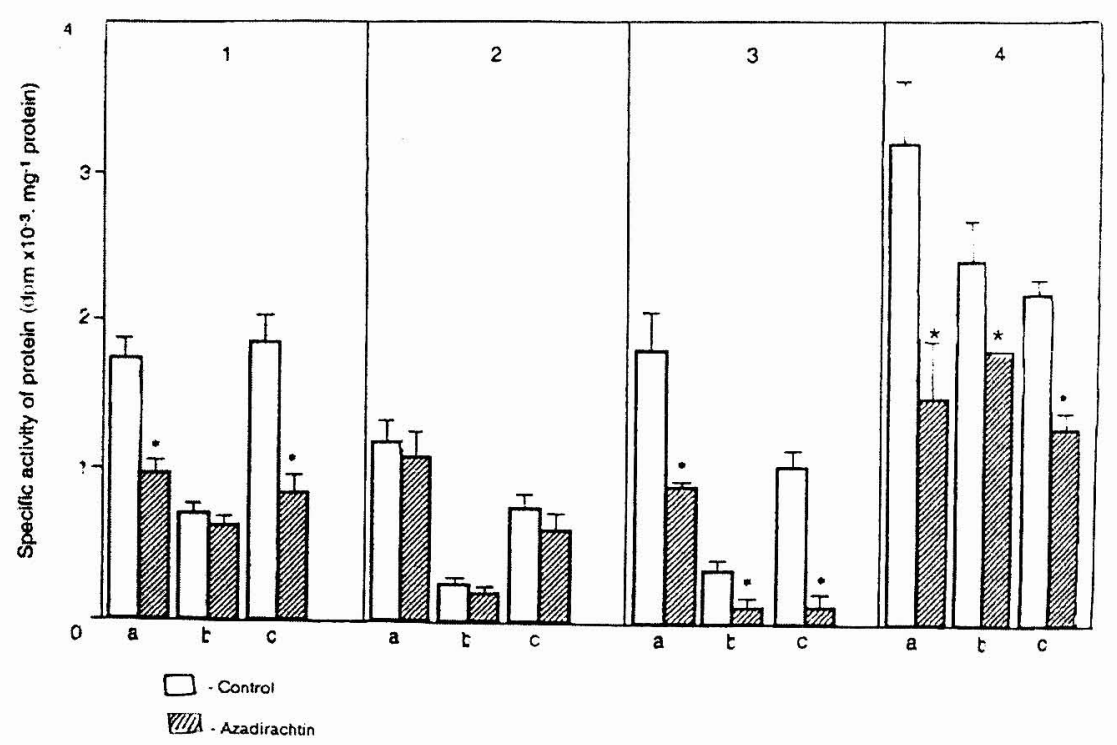

\section{Figure 7: Effect of corpus cardiacum extract and azadirachtin on incorporation of ${ }^{3} \mathrm{H}$-glycine into protein of specific tissues}

(a) Control experiment; (b) locusts were head ligatured 12 hours before injection of ${ }^{3} \mathrm{H}$-glycine; (c) locusts were head ligatured 12 hours before injection of ${ }^{3} \mathrm{H}$-glycine and then the extract of corpus cardiacum was injected into the haemolymph 3 hours before injection of radiolabelled amino acid. The values represent the mean $( \pm \mathrm{SD})$ of 4 locusts.

1. Fat body $\quad$ 2. Haemolymph $\quad$ Ovary $\quad$ Mid-gut

* Significantly different from the appropriate control experiment

Figure 8 shows the clearance of ${ }^{3} \mathrm{H}$-glycine form the haemolymph of ligatured control locusts and ligatured azadirachtin treated locusts compared with results of the unligatured insects. The results show that the rate of removal of labelling in the haemolymph is not affected by ligation or azadirachtin.

\section{Experiments in vitro}

\section{Incorporation of ${ }^{3} \mathrm{H}$-glycine into the protein of isolated tissues}

Table 1 shows the effects of corpus cardiacum extracts and azadirachtin both separately and together, on the incorporation of labelled glycine into proteins of the fat body, the ovary and the mid-gut. The effect of the neurohormonal extracts was to double the incorporation of the label in the fat body, the ovary and to increase it by $60 \%$ in the gut. These results were statistically highly significant. 


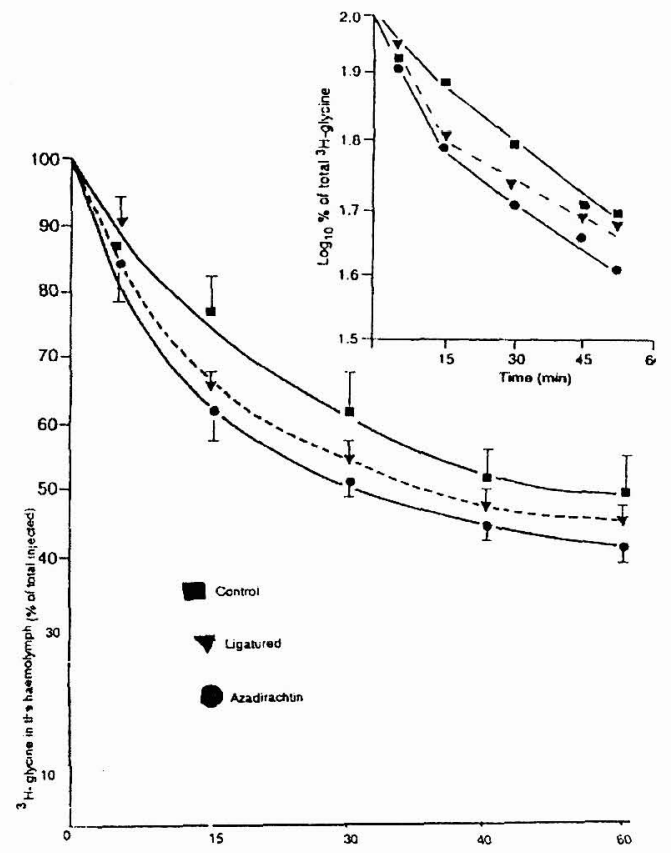

Figure 8: Effect of head -ligaturing in the clearance of ${ }^{3} \mathrm{H}$-glycine from the haemolymph of the locusts.

The points are the mean of 4 locusts, and the vertical bars indicate the standard deviation. The upper curve indicates the semi-logarithmic representations of the characteristic of the uptake of ${ }^{3} \mathrm{H}$-glycine from the locust haemolymph.

Table 1: Effect of the corpus cardiacum extract on the inhibition due to added azadirachtin on the level of incorporation of ${ }^{3} \mathrm{H}$-glycine into specific tissues of the locusts in vitro.

Tissue Specific activity (dpm. $\mathrm{mg}^{-1}$ of protein)

Conditions

1 2 3 4

Fat body $8850 \pm 721 \mathrm{a}$ $17550 \pm 1032 b$ $6202 \pm 653 a$ $7673 \pm 580 a$

Ovary $8919 \pm 943 a$ $19096 \pm 565 b$ $7546 \pm 718 \mathrm{a}$ $8431 \pm 467 a$

Mid-gut $5432 \pm 416 \mathrm{a}$ $8597 \pm 717 \mathrm{~b}$ $2212 \pm 204 \mathrm{c}$ $3367 \pm 216 \mathrm{c}$

(1) control; (2) pre-incubated with the extract of one corpus cardiacum for $30 \mathrm{~min}$; (3) pre-incubated with both corpus cardiacum extract and azadirachtin for $30 \mathrm{~min}$; (4) pre-incubated with azadirachtin only for $30 \mathrm{~min}$. The results are the means (+SD) of 4 locusts. The letters indicate statistical significance for each tissue, i.e, those means with the same letters do not differ significantly. Those with different letters are significantly different at $\mathbf{p}<0.01$. 
The addition of azadirachtin into the incubates had the effect of eliminating completely the effect of the crude hormonal extracts. In the case of the fat body and the ovary, although azadirachtin reduced the incorporation to a level below that of the control, the reductions were not statistically significant $(p>0.05)$. However, in the case of the gut, azadirachtin alone, as well as in the presence of the tissue extract, reduced the incorporation of label to an average of $50 \%$ of that of the control value.

\section{Heat lability of crude corpus cardiacum extract}

The simple experiment to determine the heat lability of the extracts of corpus cardiacum showed that a $10 \mathrm{~min}$ boiling eliminated the stimulatory effect on protein metabolism, suggesting that the active components are heat inactivated (Table 2).

Table 2: Investigation of the effects of boiled extracts of corpus cardiacum on the incorporation of ${ }^{3} \mathrm{H}$-glycine into the fat body of the locusts in vitro.

\begin{tabular}{lc}
\hline The experiment & $\begin{array}{c}\text { Specific activity } \\
\left.\text { (dpm. } \text { mg }^{-1} \text { of protein }\right)\end{array}$ \\
\hline Control & 8859 \\
Unboiled extract & 17550 \\
5 min boiled extract & 15391 \\
10 min boiled extract & 9110 \\
\hline
\end{tabular}

The results are the means of duplicate experiments which did not differ from each other by $>10 \%$.

\section{DISCUSSION}

The experiments reported were performed in order to examine the effects of azadirachtin on protein synthesis in various tissues of the adult female locust by following the incorporation of amino acid into proteins. The age of the locusts was 7 days after the final ecdysis because these represent the peak of protein synthesis in maturing females. The amino acid, glycine was selected as appropriate for following protein synthesis in the different tissues based on previous work. ${ }^{7}$

Measurement of haemolymph levels of radiolabel shows that approximately $40 \%$ of the radioactivity was lost from the haemolymph 30 minutes after the injection. The rate of uptake of the amino acid is exponential, but does not follow a simple pattern. At least two separate exponentials with different rate constants may be distinguished. Within the first 30 minutes, the uptake is very fast, suggesting that most of the radiolabel can be taken up into the widely distributed fat body where 
much protein metabolism takes place. These results are consistent with the results published by Mordue et al., for untreated locusts. ${ }^{11}$

When a physiologically effective dose of azadirachtin ( $3 \mu \mathrm{g}$ azadirachtin/g body weight) was injected, it induced an inhibitory effect on the incorporation of the radiolabelled amino acid into the protein of the whole locusts suggesting a general effect.

In untreated locusts, the sequence of incorporation of labelled glycine into the proteins of the fat body, the haemolymph and ovary differs slightly from what was previously reported by Hill,(1965). ${ }^{7}$ The previous authors found a clear progression of label first into the fat body, then haemolymph, and finally into the ovary, which was consistent with the idea that the source of the bulk of the ovarian proteins was the fat body. The results here suggest a much higher and earlier incorporation into the ovary, compared to the haemolymph, indicating that the ovary is more capable of synthesizing its own proteins than was earlier believed.

The profound effect of azadirachtin on reducing the incorporation of label into the ovarian protein is likely to be mainly due to a direct effect on that tissue. This would help to explain the fact that the clear-cut reduction of protein synthesis by azadirachtin shown by fat body and ovary is not apparent in haemolymph.

Although it is clear that the neuroendocrine system is involved in the control of protein turnover in the fat body of the female desert locust, the effect of the neuroendocrine system is complicated. Following elimination of neurohormone release by head ligation, the level of incorporation of both the azadirachtin-treated and the control locusts was significantly reduced, but only in the control head-ligatured female locusts the incorporation level could be restored to normal by injection of an extract of corpus cardiacum 3 hours before injection of the radiolabelled amino acid. This suggests that azadirachtin has a specific effect on the action of corpus cardiacum extract. These results are comparable with the in vitro results which demonstrate that the tissues incubated with a corpus cardiacum extract showed significantly higher $(p<0.05)$ incorporation rates in the control locusts but not for azadirachtin-treated locust tissues. It is probable that the low level of incorporation following cautery of the cerebral neurosecretory cells is the result of such a direct effect upon protein synthesis. Either cautery of the cerebral neurosecretory cells or allactectomy in the desert locust results in the inhibition of oocyte growth. ${ }^{12,13}$ In the immature female locusts with both these operations, the incorporation rate of ${ }^{14} \mathrm{C}$-glycine into the fat body protein does not increase, as it does in control animals, but slowly decreases. The decrease of incorporation is more rapid after neurosecretory cell cautery than after allactectomy, and the incorporation rate reaches a lower level. ${ }^{7}$ 
The direct effect of azadirachtin on the fat body, the ovary and the haemolymph is consistent with the prevention of stimulatory action of neurohormones on protein synthesis, but the mid-gut shows a different effect. The level of incorporation of amino acids into the gut protein of the head-ligatured control locusts is higher than the ligatured azadirachtin-treated locusts suggesting an additive effect. The incorporation level of both these groups is lower than in control insects. Azadirachtin apparently has a direct effect on protein synthesis of the mid-gut which is independent of neurohormones. The direct effect of azadirachtin upon gut muscle contraction both in vivo and in vitro has been recorded and it reduces the activity of most of the digestive enzymes which are secreted by the mid-gut. ${ }^{14,15}$ The inhibition of gut contraction by azadirachtin has a marked effect on its passage through the gut. This results not only in lower faecal production but in a lower rate of absorption of food. Studies on mid-gut tissue show that the epithelial cells are greatly disrupted by the action of azadirachtin..$^{14,16}$ There is also a suppression level of feeding, because feeding is not initiated in the locust until the foregut and hindgut are relatively empty. ${ }^{17,18}$ Although these are chemo-receptors on the mouthparts, an antifeedant effect is still produced by its effect on the passage of food through the gut. ${ }^{19}$ The effect of neurohormones on the mid-gut of other insects has also been studied. It is clear that the neurosecretory system can affect the synthesis of digestive enzymes of the mid-gut. ${ }^{20}$ In Manduca sexta, mid-gut wall and in Spodoptera litura, azadirachtin significantly affects the digestive enzymes such as protease, amylase and invertase. Therefore, the low level of incorporation of amino acid into the gut proteins in the azadirachtin-treated locusts could be due to the secondary antifeedant effect of azadirachtin. Thus a direct effect of azadirachtin on gut protein synthesis can account for some part of secondary antifeedant effect.

It becomes clear that although there is a very general effect of azadirachtin on protein biosynthesis, its mode of action varies from tissue to tissue, and is selective even within one tissue. Thus, while the effect on the gut appear to be general, the effect on the fat body and the ovary is only to negate the stimulatory effects of neurohormonal extracts. It is clear from the lack of effect on the protein biosynthesis induced by juvenile hormone, and from the previously published data, that only some proteins are affected..$^{21}$ In the light of these differences, it is difficult to propose a single common mechanism underlying an apparently general effect on protein synthesis.

\section{Acknowledgement}

The authors gratefully acknowledge the Association of Commonwealth Universities, U.K. for financial support. 


\section{References}

1 Butterworth J.H. \& Morgan E. D. (1971). Investigation of the locust feeding inhibition of the seeds of the neem tree Azadirachta indica. Journal of Insect Physiology 17: 967 -977.

2 Rembold H., Forster H., Czoppelt Ch., Rao P. J. \& Sieber K. P. (1983). The azadirachtins, a group of insect growth regulators from neem tree. Proceedings of the 2nd International Neem Conference Rauischholhausen, pp.153-162.

3 Rembold H., Muller Th. \& Subrahmanyam B. (1988). Tissue - specific incorperation of azadirachtin in the Malpigian tubules of Locusta migratoria. X. Naturwissenschften. 43c, 903-907.

4 Subrahmanyam B. \& Rembold H. (1989). The effect of azadirachtin on the endocrine control of moulting in Locusta migratori. Cell and Tissue Research. 256: 513-517.

5 Kauser G. \& Koolman J. (1984). Ecdysteroid receptor in tissues of the blowfly Calliphora vicina. In: Advances in Invertebrate Reproduction (Ed. W. Engels) 3 p. 602 , Elsevier, Amsterdam.

6 Paranagama P.A., Lovell H., Denholm A.A., Ley S. V., Connolly J.D. \& Strang, R.H.C. (1993). Uptake, retention, metabolism and excretion of $\left[22,23-{ }^{3} \mathrm{H}_{2}\right]$ dihydroazadirachtin in Schistocerca gregaria. Journal of Insect Physiology 39: 935-943.

7 Hill L. (1965). The incorporation of ${ }^{14} \mathrm{C}$-glycine into the proteins of the fat body of the desert locust during ovarian development. Journal of Insect Physiology 11: 1605-1615.

8 Schroeder D. R. \& Nakanishi K.A. (1957). A simplified separation procedure for azadirachtin. Journal of Natural Products 50: 241.

9 Yamasaki R. B., Klocke J.A., Lee M.S., Stone G.A. \& Darlington M.V. (1986). Isolation and purification of azadirachtin from neem (Azadirachta indica) seeds using flash chromatography and high perfomance liquid chromatography. Journal of Chromatography 356: 220-226.

10 Lowry O.H., Rosebrough N.J., Farr A.L. \& Randall R.J. (1951). Protein measurement with the folin phenol reagent. Journal of Biological Chemistry 193: $265-275$. 
11 Mordue A.J. \& Highnam K.C. (1973). Incorporation of cysteine into the cerebral neurosecretory system of adult locusts. General and Comparative Endocrinology 20: 351-357.

12 Highnam K.C. (1962). Neurosecretory control of ovarian development in Schistocerca gregaria. Quarterly Journal of Microscopical Science 12: 379390 .

13 Highnam K.C., Lusis O. \& Hill L. (1963). The role of the Corpora allata during oocyte development in Schistocerca gregaria. Journal of Insect Physiology 9: 587-596.

14 Mordue (luntx) A.J., Cottee P.K. \& Evans K.A. (1985). Azadirachtin: its effect on gut mortality, growth and moulting in locusts. Physiological Entomology 10: 431-437.

15 Timmins W.A. \& Rynolds S.E. (1992). Azadirachtin inhibits secretion of trypsin in midgut of Manduca sexta catapillars: reduced growth due to impaired protein digestion. Entomologia Experimentalis et Applicata 63: 47-54.

16 Cottee P.K. (1984). A physiological investigation into the role of secondary plant compounds as feeding deterrents. Ph.D. thesis, University of Aberdeen, U.K.

17 Bernays E.A. \& Chapman R.F. (1973). The regulation of feeding in Locusta migratoria: internal inhibitory mechanisms. Entomologia Experimentalis et Applicata 16: 329-342.

18 Simpson S.J. (1983). The role of volumetric feed-back from the hindgut in the regulation of meal size in fifth-instar Locusta migratoria nymphs. Physiological Entomology 8: 451-467.

19 Blaney W.M. \& Winstanley C. (1980). Chemosensory mechanism of locusts in relation to feeding: the role of some secondary plant compounds. Insect Neurobiology and Pesticide Action (Neurotox 1979), Society of Chemical Industry, London 383-389.

20 Thomson E. \& Noller I. (1963). Influence of neurosecretory cells and corpus cardiacum on intestinal proteinase activity in the adult Calliphora erythrocephala Meig., Journal of Experimental Biology 40: 301-322.

21 Annadurai R.S. \& Rembold H. (1993). Azadirachtin A modulates the tissue specific 2D polypeptides patterns of the locusts, Schistocerca gregaria. Naturwissenschften 80: 127-130. 